\title{
Synthesis and Crystal Structure Studies of Mitomycin C Dihydrate
}

\author{
Yingqi Feng*, Yongshou Chen*, Yixin Ren*, Heng Zhang\#, Shuang Cao\# \\ Key Laboratory for Green Chemical Process of Ministry of Education, School of Chemical Engineering and Pharmacy, Wuhan \\ Institute of Technology, Wuhan, China \\ Email: ${ }^{*}$ caoshuangknight@163.com, ${ }^{\#}$ zhzpthm@163.com
}

How to cite this paper: Feng, Y.Q., Chen, Y.S., Ren, Y.X., Zhang, H. and Cao, S. (2020) Synthesis and Crystal Structure Studies of Mitomycin C Dihydrate. Crystal Structure Theory and Applications, 9, 13-21. https://doi.org/10.4236/csta.2020.92002

Received: February 23, 2020

Accepted: March 23, 2020

Published: March 26, 2020

Copyright (c) 2020 by author(s) and Scientific Research Publishing Inc. This work is licensed under the Creative Commons Attribution International License (CC BY 4.0).

http://creativecommons.org/licenses/by/4.0/

\begin{abstract}
The absolute configuration of mitomycin $\mathrm{C}$ was determined by X-ray single crystal diffraction $(\mathrm{CuK} \alpha)$, and a new crystalline dihydrate of mitomycin $\mathrm{C}$ had been prepared. The experiment result provides a definitive answer to the real absolute configuration of mitomycin $\mathrm{C}$ and may put an end to the dispute that baffles researchers for decades. At the same time, some contentious structures about the mitomycin C in American Pharmacopoeia USP36-NF31, Chinese pharmacopoeia 2015 edtion and numbers of literatures are marked. The absolute configuration is also verified by $1 \mathrm{D}\left({ }^{1} \mathrm{H}\right.$ and $\left.{ }^{13} \mathrm{C}\right)$ and $2 \mathrm{D}$ (HSQC, HMBC, ${ }^{1} \mathrm{H}-{ }^{1} \mathrm{H}$ COSY and NOESY) NMR studies indirectly. Powder X-ray diffraction (PXRD) pattern of the mitomycin $\mathrm{C}$ dihydrate is similar to that calculated for it, which suggests that the purity of sample is excellent.
\end{abstract}

\section{Keywords}

Crystal Structure, Dihydrate, Absolute Configuration, Mitomycin C

\section{Introduction}

Mitomycin C, an antibiotic antitumor drug [1] [2] [3], was first extracted from Streptomyces species in 1958, and its chemical structure was determined in 1963 [4] [5] [6]. Surprisingly, although mitomycin C has been successfully used in clinical circumstance for more than thirty years [6] [7] [8] [9], there are still many arguments about its absolute configuration [5] [10] [11] (Figure 1).

American Pharmacopoeia USP36-NF31 and Chinese pharmacopoeia 2015 edtion define configuration B as the standard structure of mitomycin C; instead, European Pharmacopoeia EP7.0, British Pharmacopeia BP2017 and Japanese Pharmacopeia JP17 define configuration A. Then, we probed further and found ${ }^{\star}$ These authors contributed equally to this work. 
out that two drugs Mitosol and Mitozytrex, approved by FDA, both record the structure as configuration B (Table 1). In Cambridge Structural Database System, S.K. Arora [10] reported different kinds of single crystal of mitomycin C, but they failed to reach a mutual agreement. The reason contributed to this question may be due to limitation of early crystallography techniques, for example, they were inclined to use molybdenum target radiography, by which radiography is hardly to obtain believable absolute configuration of compound, rather than copper target.

In this paper, we determined the absolute configuration of mitomycin $\mathrm{C}$ by $\mathrm{X}$-ray single crystal diffraction $(\mathrm{CuK} \alpha)$, analyzed its structure by $1 \mathrm{D}$ and $2 \mathrm{D}$ NMR spectra, and prepared a new crystalline. Most importantly, the result of our experiment can provide a definitive answer and put an end to the dispute about the real absolute configuration of mitomycin $\mathrm{C}$.<smiles>CO[C@]12[C@H](COC(N)=O)C3=C(C(=O)C(C)=C(N)C3=O)N1C[C@H]1N[C@H]12</smiles>

$((1 \mathrm{a} S, 8 S, 8 \mathrm{a} R, 8 \mathrm{~b} S)$-6-amino-8a-methoxy-5-methyl-4,7-dioxo1,1a,2,4,7,8,8a,8b-octahydroazirino[2',3':3,4]pyrrolo[1,2-a]indol8-yl)methyl carbamate

Configuration A

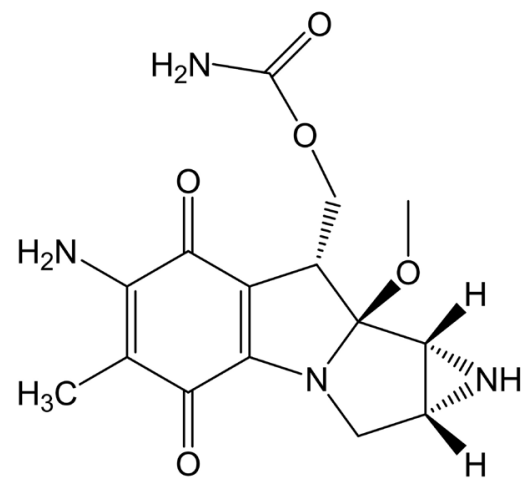

(( $(\mathrm{a} R, 8 R, 8 \mathrm{a} S, 8 \mathrm{~b} R)$-6-amino-8a-methoxy-5-methyl-4,7-dioxo$1,1 \mathrm{a}, 2,4,7,8,8 \mathrm{a}, 8 \mathrm{~b}$-octahydroazirino[2',3':3,4]pyrrolo[1,2-a]indol-8yl)methyl carbamate Configuration B

Figure 1. Two configurations of mitomycin $\mathrm{C}$ reported from literatures.

Table 1. Some document record about the structure of mitomycin C.

\begin{tabular}{cc}
\hline Pharmacopoeia & Record Structure \\
\hline USP36-NF31 & $\mathrm{B}$ \\
$C P 2015$ & $\mathrm{~B}$ \\
$E P 7.0$ & $\mathrm{~A}$ \\
BP2017 & $\mathrm{A}$ \\
JP17 & $\mathrm{A}$ \\
Drug approved by FDA & \\
Mitosol (FDA2012) & $\mathrm{A}$ \\
Mitozytrex (FDA2002) & $\mathrm{B}$ \\
Literature & \\
S.K. Arora & $\mathrm{B}$ \\
K. Ogawa & $\mathrm{B}$ \\
\hline
\end{tabular}




\section{Experimental}

\subsection{Reagents and Instruments}

All reagents were obtained from commercial sources and used without further purification. ${ }^{1} \mathrm{H}$ NMR and ${ }^{13} \mathrm{C}$ NMR spectra were recorded on a Varian Unity $400 \mathrm{MHz}$ spectrometer. 2D NMR were recorded by a Varian Unity $100 \mathrm{MHz}$ NMR spectrometer and used to assist in structure elucidation. DMSO- $d_{6}$ was used as the solvent in both of $1 \mathrm{D}$ and $2 \mathrm{D}$ NMR spectra (DMSO- $d_{6}: 2.49 \mathrm{ppm}$ for ${ }^{1} \mathrm{H}$ and $39.9 \mathrm{ppm}$ for ${ }^{13} \mathrm{C}$ ). The powder X-ray diffraction (PXRD) pattern was recorded on crushed single crystals in the $2 \theta$ range of $6^{\circ}-55^{\circ}$ with a $\mathrm{CuK} \alpha$ radiation.

\subsection{Preparation of Single Crystal}

Dissolve mitomycin C (200 $\mathrm{mg}$ ) in water $(40 \mathrm{ml})$, then the solution was stirred in room temperature for 20 minutes [12]. After the violet insoluble substance was filtered, chloroform $(10 \mathrm{ml})$ was added into the violet aqueous solution slowly. Keep the mixture in a sealed container stored in a dark place at room temperature and many purple-dark prismatic crystals appeared on the container wall after 3 days.

\subsection{X-Ray Structure Determination}

A purple-dark single crystal with approximate dimensions of $0.12 \mathrm{~mm} \times 0.10$ $\mathrm{mm} \times 0.08 \mathrm{~mm}$ was selected. The data was collected by a Rigaku Saturn944 CCD diffractometer (CuK $\alpha$ radiation) in the ranges of $4.688^{\circ} \leq \theta \leq 72.379^{\circ},-11 \leq h \leq$ $11,-15 \leq k \leq 15$ and $-16 \leq 1 \leq 16$. A total of 21,504 reflections were collected, of which 3386 were independent $($ Rint $=0.0641)$. The full-matrix least-squares refinement on $F^{2}$ (SHELXL-97) was performed with non-hydrogenatoms refined anisotropically. The final $R=0.0534$ and $w R=0.1133$ for 3186 observed reflections with $\left(F^{2} \geq 2 \sigma F^{2}\right)$ and $R=0.0546$ and $w R=0.1154$ for all data.

\section{Results and Discussion}

\subsection{NMR Spectra}

The ${ }^{1} \mathrm{H},{ }^{13} \mathrm{C}, \mathrm{HSQC}, \mathrm{HMBC},{ }^{1} \mathrm{H}-{ }^{1} \mathrm{H}$ COSY NMR spectra allowed the assignments of all the protons to their bonding carbons (Table 2), which confirmed the planar structure of the molecule correct. There was a striking contrast between the signals of two protons linking to $\mathrm{C}_{3}\left(\mathrm{C}_{13}\right)$ in ${ }^{1} \mathrm{H}$ NMR spectrum $\left(\delta \mathrm{H}_{3}: 4.00,3.35\right.$; $\left.\delta \mathrm{H}_{13}: 4.53,4.10\right)$ and this phenomenon could be ascribed to the chiral structure of $\mathrm{C}_{2}$ and $\mathrm{C}_{10}$.

The relative configuration of compound was assigned by NOESY spectra, in particular, by comparing the ${ }^{1} \mathrm{H}^{1} \mathrm{H}$ COSY (Figure 2) and NOESY (Figure 3) spectra, we observed that $\mathrm{H}_{15}$ had no ${ }^{1} \mathrm{H}-{ }^{1} \mathrm{H}$ COSY correlations with $\mathrm{H} 1, \mathrm{H}_{2}, \mathrm{H}_{3}$, $\mathrm{H}_{10}$ because of the long distance, but distinct NOESY correlations of $\mathrm{H}_{15}$ with $\mathrm{H}_{1}$, $\mathrm{H}_{2}, \mathrm{H}_{3}, \mathrm{H}_{10}$ could be found. At the same time, NOESY correlations between $\mathrm{H}_{15}$ 
Table 2. ${ }^{1} \mathrm{H}(400 \mathrm{MHz})$ and ${ }^{13} \mathrm{C}$ NMR $(100 \mathrm{MHz})$ Chemical Shifts of mitomycin in DMSO- $d_{6}$ at $300 \mathrm{~K}$.

\begin{tabular}{|c|c|c|c|c|c|}
\hline Position & $\delta_{H}$ & $\delta_{C}$ & ${ }^{1} \mathrm{H}-{ }^{-1} \mathrm{H} \operatorname{Cos} \mathrm{Y}$ & HMBC & NOESY \\
\hline $\mathrm{C}_{1}$ & $2.80 \mathrm{~s}$ & 35.45 & $\mathrm{~N} 1$ & 3 & $\mathrm{~N} 1,15$ \\
\hline $\mathrm{C}_{2}$ & $2.71 \mathrm{~s}$ & 31.55 & $\mathrm{~N} 1,3$ & 3 & $\mathrm{~N} 1,3,15$ \\
\hline $\mathrm{C}_{3}$ & $4.01,3.35 \mathrm{dd}(12)$ & 49.66 & 2 & $1,2,11$ & 2,15 \\
\hline $\mathrm{C}_{4}$ & - & 155.31 & - & 10 & - \\
\hline $\mathrm{C}_{5}$ & - & 176.87 & - & 10,12 & - \\
\hline $\mathrm{C}_{6}$ & - & 102.58 & - & 12 & - \\
\hline $\mathrm{C}_{7}$ & - & 149.07 & - & 12 & - \\
\hline $\mathrm{C}_{8}$ & - & 175.25 & - & - & - \\
\hline $\mathrm{C}_{9}$ & - & 109.10 & - & 10 & - \\
\hline $\mathrm{C}_{10}$ & $3.40 \mathrm{~m}$ & 42.76 & 13 & $4,5,9,11$ & 15 \\
\hline $\mathrm{C}_{11}$ & - & 105.75 & - & $\mathrm{N} 1,15,10,3$ & - \\
\hline $\mathrm{C}_{12}$ & $1.67 \mathrm{~s}$ & 8.38 & - & $5,6,7$ & - \\
\hline $\mathrm{C}_{13}$ & $4.55,4.1 \mathrm{tt}$ & 60.90 & 10 & - & - \\
\hline $\mathrm{C}_{14}$ & - & 156.60 & - & - & - \\
\hline $\mathrm{C}_{15}$ & $3.11 \mathrm{~s}$ & 49.17 & - & 11 & $1,2,3,10$ \\
\hline $\mathrm{N}_{1}$ & $1.80 \mathrm{t}$ & - & 1,2 & - & 1,2 \\
\hline $\mathrm{N}_{3}$ & $7.05 \mathrm{~s}$ & - & - & - & - \\
\hline $\mathrm{N}_{4}$ & $6.45,6.70 \mathrm{ss}$ & - & - & - & - \\
\hline
\end{tabular}

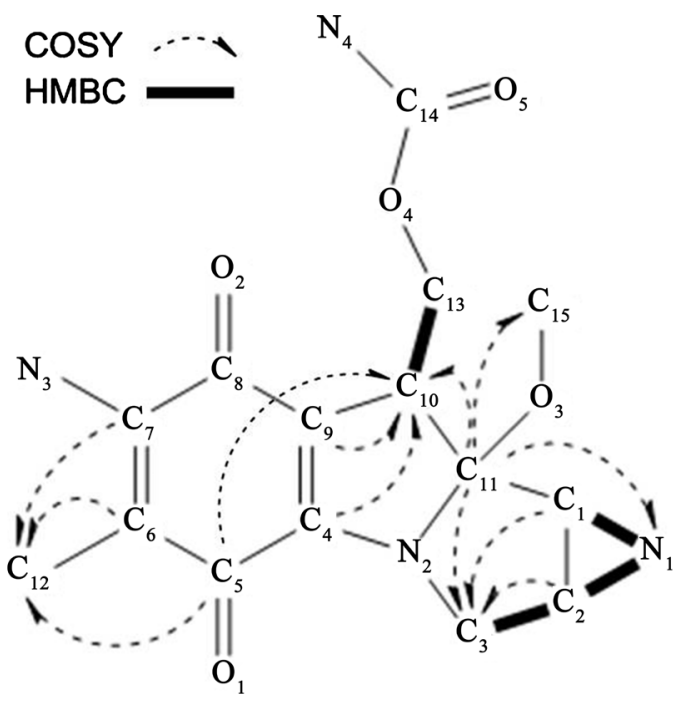

Figure 2. Key COSY and HMBC correlations of mitomycin C.

and $\mathrm{H}_{13}$ or $\mathrm{H}_{\mathrm{N} 1}$ could not be observed. All this information suggested that $\mathrm{H}_{15}$ and $\mathrm{H}_{1}, \mathrm{H}_{2}, \mathrm{H}_{3}$ are on the same side of the mitomycin $\mathrm{C}$, in other words, $\mathrm{C}_{15}$ is on the other side of $\mathrm{C} 13$ and $\mathrm{N}_{1}$ which could be ascribed to the bond of $\mathrm{C}_{11}-\mathrm{O}_{3}$ had different orientation with $\mathrm{C}_{10}-\mathrm{C}_{13}$ and $\mathrm{C}_{1}-\mathrm{N}_{1}$. 
Unfortunately, the 1D and 2D NMR spectra did not provide enough information to ascertain the absolute configuration of mitomycin $C$ [13] [14]. Thus, a single crystal of mitomycin $\mathrm{C}$ was prepared.

\subsection{Description of the Single Crystal Structure}

The absolute configuration of the title compound is shown in Figure 4. These configurations at $C_{10}, C_{11}, C_{1}$ and $C_{2}$ are, respectively, (S), (R), (S) and (S) in our crystal, which structure is in accordance with configurations $\mathrm{A}$, but is exactly opposite to configurations B (Figure 5).

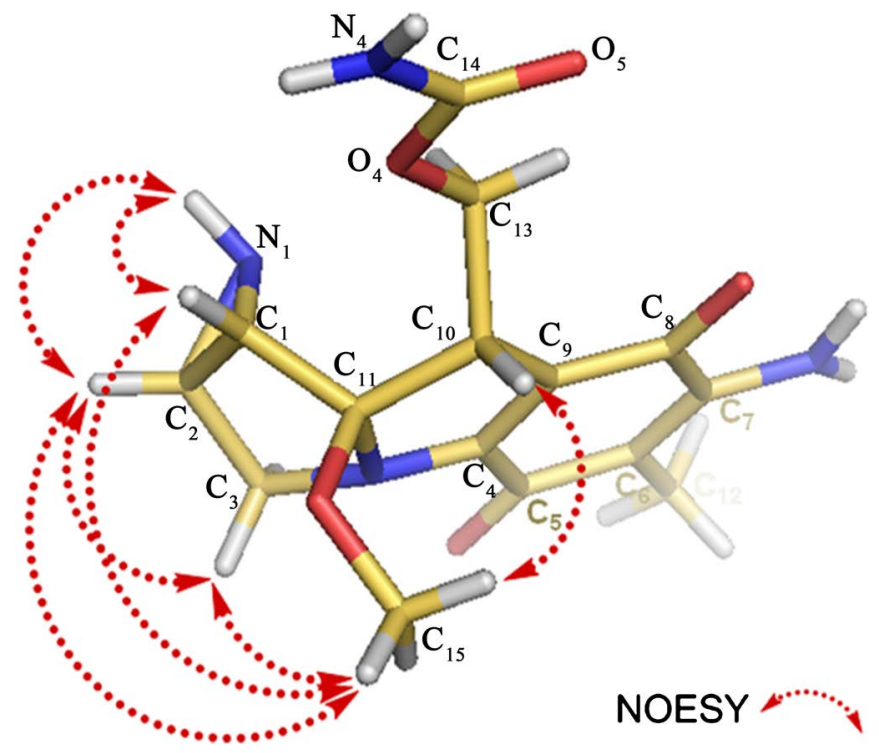

Figure 3. Key NOESY correlations and X-ray crystallographic structure of mytomycin C.

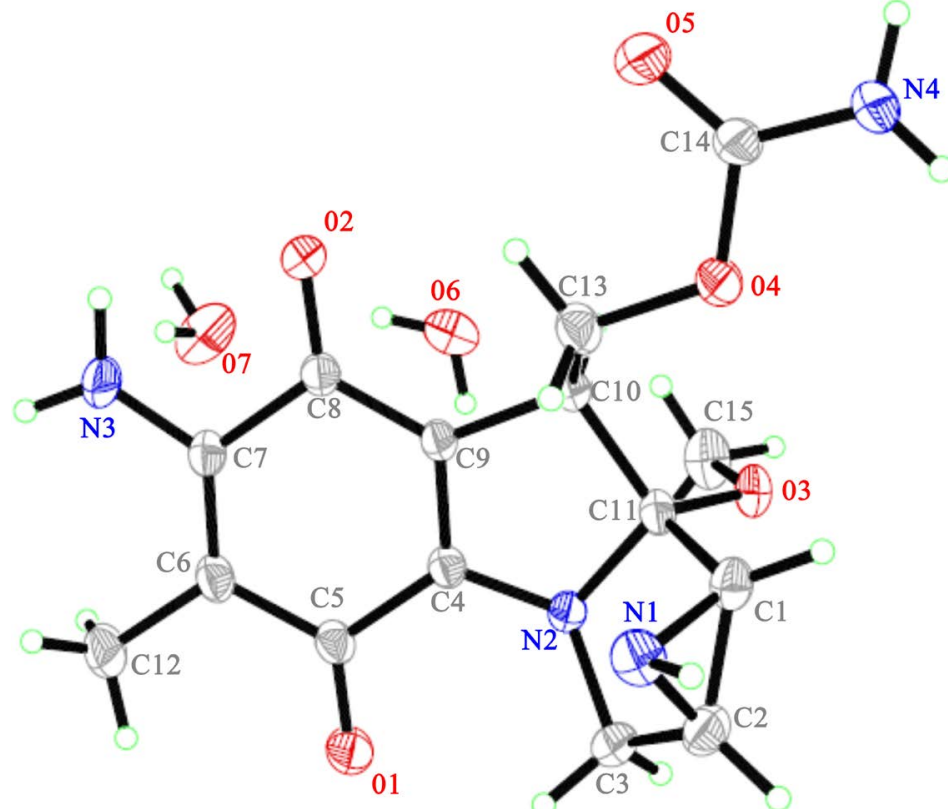

Figure 4. The X-ray crystal structure of mitomycin C dihydrate (CCDC 993490), with displacement ellipsoids drawn at the $30 \%$ probability level. 
The distance from $\mathrm{C}_{13}$ to plane $\mathrm{B}$ (Figure 6) is 1.1847(0.0029) $\AA$, and the angle of plane $\mathrm{A}$ to $\mathrm{B}, \mathrm{B}$ to $\mathrm{C}, \mathrm{C}$ to $\mathrm{D}$ and $\mathrm{D}$ to A are, respectively, $2.19(0.02)^{\circ}, 46.25$ $(0.07)^{\circ}, 81.18(0.07)^{\circ}$ and $54.99(0.09)^{\circ}$. Torsion angles in carbamoyloxymethyl side chain $\left(\mathrm{C}_{14}-\mathrm{O}_{4}-\mathrm{C}_{13}-\mathrm{C}_{10}\right)$ is $115.87(0.23)^{\circ}$, and in methoxyl group $\left(\mathrm{C}_{15}-\mathrm{O}_{3}-\mathrm{C}_{11}-\mathrm{N}_{2}\right)$ is $56.36(0.27)^{\circ}$. This structure is demarcated by the benzoquinone cycle, carbamoyloxymethyl side chain on one side, and two water molecules on other side (Figure 3). The selected bond lengths and bond angles are given in Figure 6.

We can observe an interesting phenomenon from Figure 7 that water molecules become the center of this unit cell, which are surrounded by the order array of mitomycin $\mathrm{C}$. The interacting with each other by hydrogen bonds (Table 3) of these mitomycin C forming a construction of "well", at the same time these water molecules are inlaid in the "well" steady because of the hydrogen bonds between water and mitomycin $\mathrm{C}$.

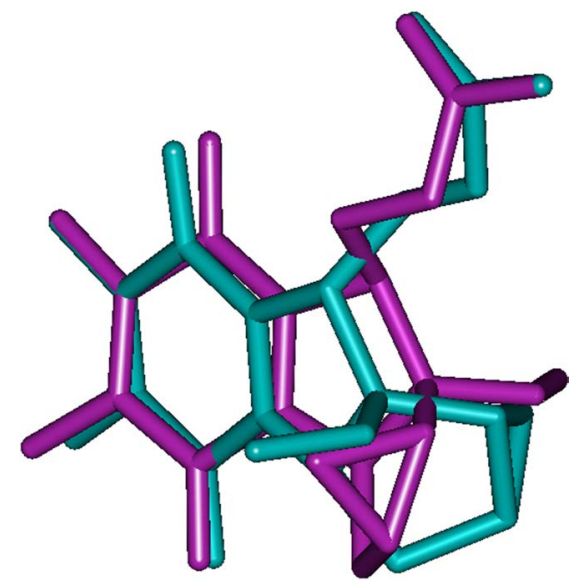

Figure 5. The molecule overlap of configuration A (purple) and configuration B (green).
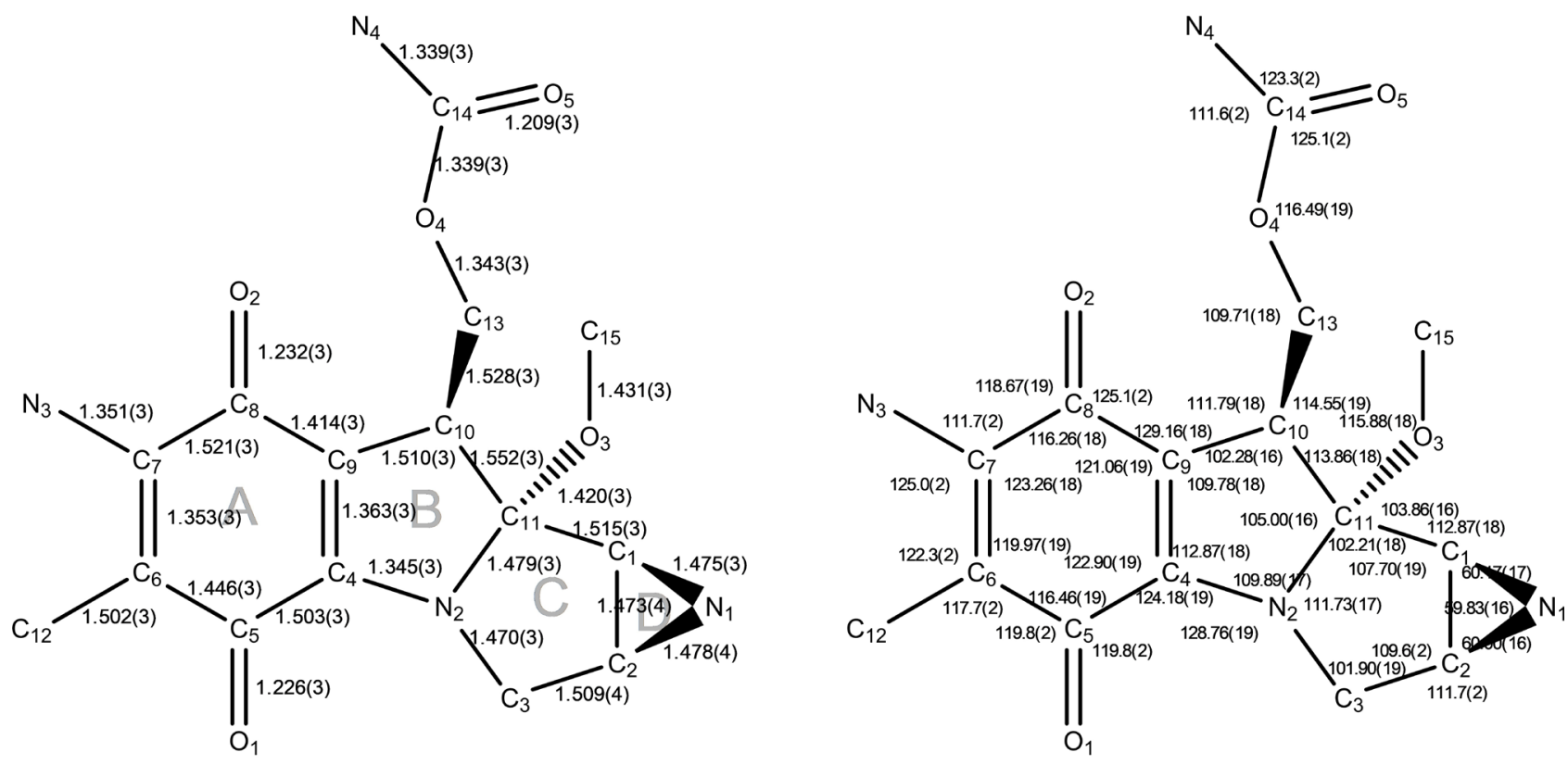

Figure 6. Bond lengths $/ \AA$ and angles $/{ }^{\circ}$ with their estimated standard deviations in parentheses. 


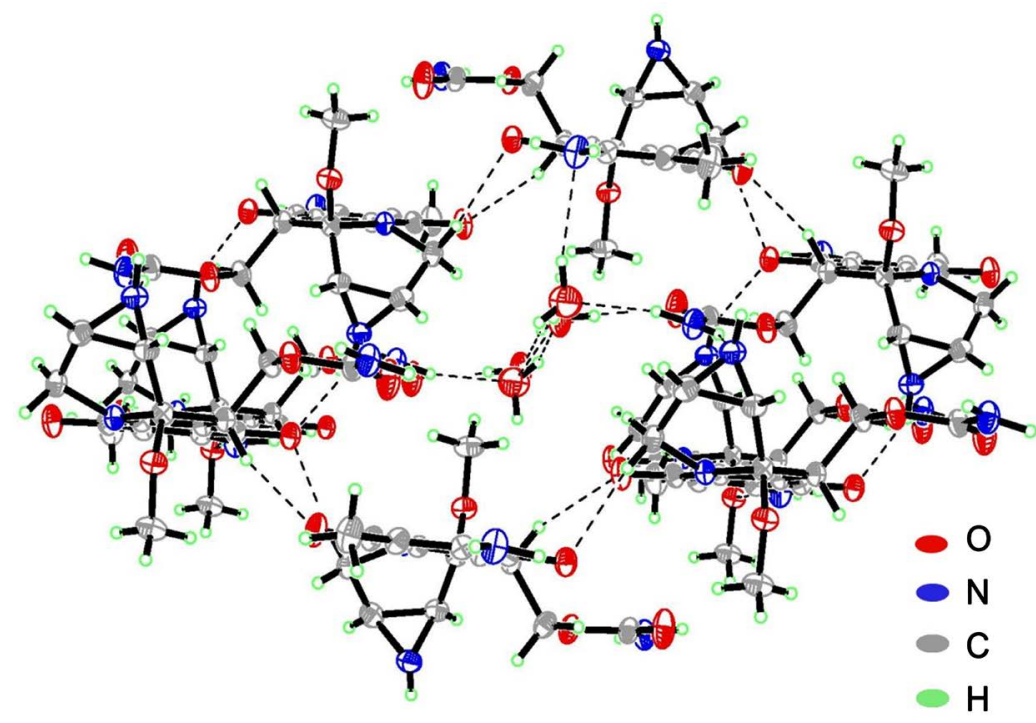

Figure 7. Molecule packing diagram of mitomycin $\mathrm{C}$ dihydrate in a unit cell.

Table 3. Hydrogen Bond Lengths ( $\AA$ ) and Bond Angles $\left({ }^{\circ}\right)$.

\begin{tabular}{ccccc}
\hline $\mathrm{D}-\mathrm{H} \cdots \mathrm{A}$ & $\mathrm{d}(\mathrm{D}-\mathrm{H})$ & $\mathrm{d}(\mathrm{H} \cdots \mathrm{A})$ & $\mathrm{d}(\mathrm{D} \cdots \mathrm{A})$ & $\angle \mathrm{DHA}$ \\
\hline $\mathrm{C}(3)-\mathrm{H}(3 \mathrm{C}) \cdots \mathrm{O}(2)^{\mathrm{a}}$ & 0.97 & 2.47 & $3.423(3)$ & 167.9 \\
$\mathrm{C}(3)-\mathrm{H}(3 \mathrm{D}) \cdots \mathrm{O}(1)$ & 0.97 & 2.46 & $2.999(3)$ & 114.9 \\
$\mathrm{C}(10)-\mathrm{H}(10) \cdots \mathrm{O}(1)^{\mathrm{b}}$ & 0.98 & 2.48 & $3.393(3)$ & 154.8 \\
$\mathrm{C}(13)-\mathrm{H}(13 \mathrm{~B}) \cdots \mathrm{N}(1)$ & 0.97 & 2.61 & $3.231(3)$ & 121.7 \\
$\mathrm{~N}(1)-\mathrm{H}(1 \mathrm{~A}) \cdots \mathrm{O}(2)^{\mathrm{c}}$ & $0.90(4)$ & $2.15(4)$ & $2.975(3)$ & $152(3)$ \\
$\mathrm{N}(3)-\mathrm{H}(3 \mathrm{~A}) \cdots \mathrm{O}(3)^{\mathrm{d}}$ & $0.89(3)$ & $2.03(3)$ & $2.903(3)$ & $168(3)$ \\
$\mathrm{N}(4)-\mathrm{H}(4 \mathrm{~A}) \cdots \mathrm{N}(1)^{\mathrm{c}}$ & $0.85(4)$ & $2.30(4)$ & $3.046(3)$ & $146(3)$ \\
$\mathrm{N}(4)-\mathrm{H}(4 \mathrm{~B}) \cdots \mathrm{O}(7)^{\mathrm{b}}$ & $0.90(5)$ & $2.17(5)$ & $3.051(4)$ & $165(4)$ \\
$\mathrm{O}(6)-\mathrm{H}(6 \mathrm{~A}) \cdots \mathrm{O}(7)$ & $0.83(3)$ & $2.07(4)$ & $2.870(5)$ & $160(5)$ \\
$\mathrm{O}(6)-\mathrm{H}(6 \mathrm{~B}) \cdots \mathrm{O}(5)^{\mathrm{a}}$ & $0.84(3)$ & $1.93(4)$ & $2.758(3)$ & $166(5)$ \\
$\mathrm{O}(7)-\mathrm{H}(7 \mathrm{~A}) \cdots \mathrm{N}(3)$ & $0.91(3)$ & $2.35(3)$ & $3.225(4)$ & $160(5)$ \\
$\mathrm{O}(7)-\mathrm{H}(7 \mathrm{~B}) \cdots \mathrm{O}(6)^{\mathrm{e}}$ & $0.88(3)$ & $1.89(4)$ & $2.703(4)$ & $153(6)$ \\
\hline
\end{tabular}

Symmetry codes: (a) $-x, y+1 / 2,-z+3 / 2$; (b) $-x, y-1 / 2,-z+3 / 2$; (c) $x-1 / 2,-y+1 / 2,-z+2$; (d) $x+1, y$, $z ;(e) x+1 / 2,-y+1 / 2,-z+1$.

\subsection{Powder X-Ray Diffraction (PXRD) Analysis}

The mitomycin $\mathrm{C}$ dihydrate is also characterized by Powder X-ray diffraction (PXRD). As shown in Figure 8, the PXRD pattern is almost consistent with its simulated spectra, indicating the sample has good purity.

\section{Conclusion}

In this research, it has been found that the absolute configuration of mitomycin $\mathrm{C}$ at $\mathrm{C}_{10}, \mathrm{C}_{11}, \mathrm{C}_{1}$ and $\mathrm{C}_{2}$ is, respectively, (S), (R), (S) and (S). This conclusion is confirmed by $\mathrm{X}$-ray single crystal diffraction with $\mathrm{Cu}$ radiation, which could give 


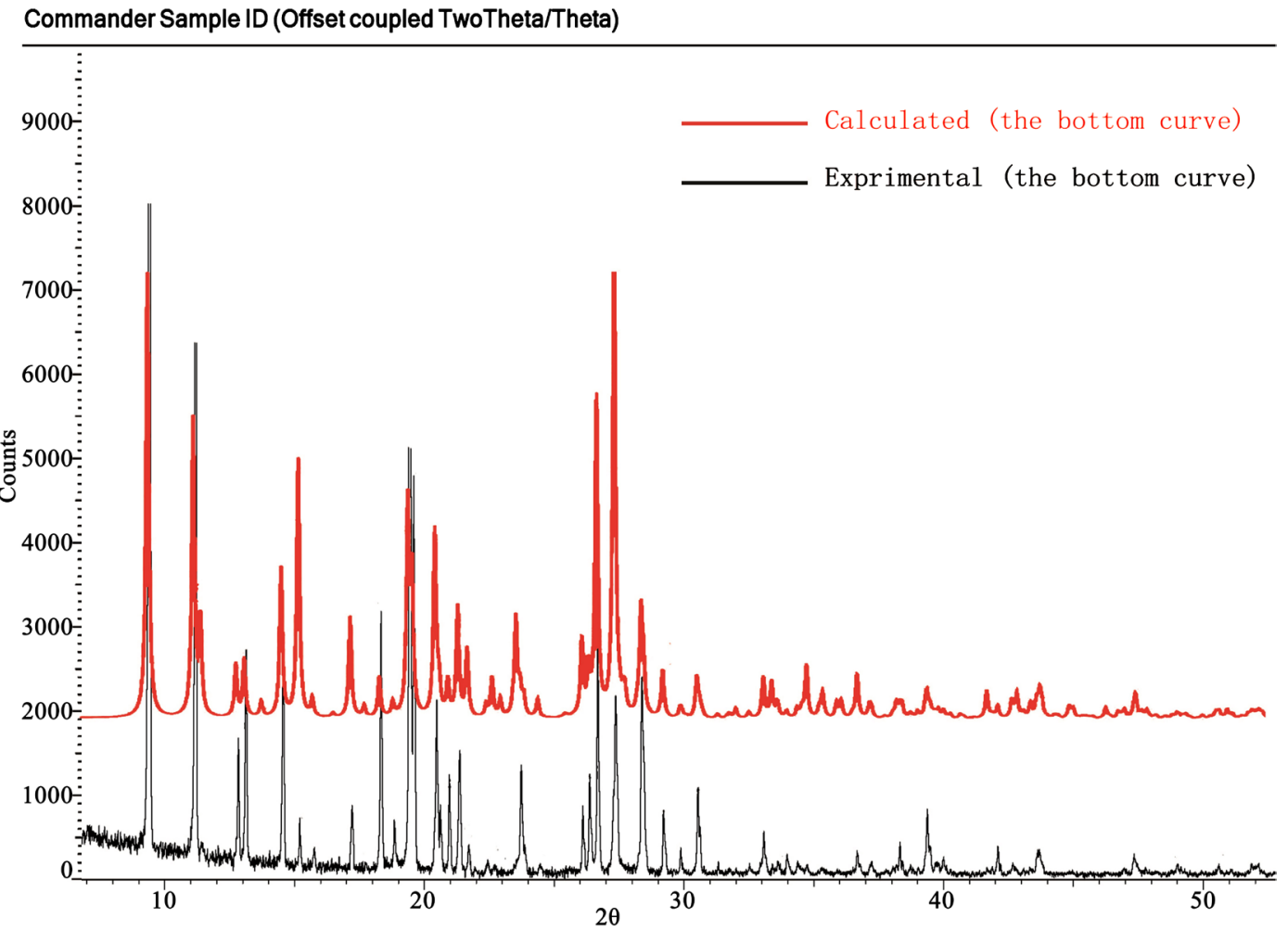

Figure 8. Experimental and calculated PXRD patterns.

a unified end to the argument about true absolute configuration of mitomycin C. In addition, the structure of mitomycin $\mathrm{C}$ also is confirmed and described in detail by $1 \mathrm{D}$ and 2D NMR spectra. What's more, a novel crystal morphology called mitomycin $\mathrm{C}$ dihydrate is obtained, which has the advantages of simple preparation and stable quality, and shows a promise to be a new drug crystal morphology.

\section{Acknowledgements}

We gratefully acknowledge financial support from the program for Graduate Innovative Fund of Wuhan Institute of Technology (No. CX2018001) and Research Fund of Wuhan Institute of Technology (No. K201756 and No. 2019018).

\section{Conflicts of Interest}

The authors declare no conflicts of interest regarding the publication of this paper.

\section{References}

[1] Karkos, P.D., Leong, S.C., Sastry, A., Assimakopoulos, A.D. and Swift, A.C. (2011) Evidence-Based Applications of Mitomycin C in the Nose. American Journal of Otolaryngology, 32, 422-425. https://doi.org/10.1016/j.amjoto.2010.07.022

[2] Crooke, S.T. and Bradner, W.T. (1976) Mitomycin C: A Review. Cancer Treatment Reviews, 3, 121-139. https://doi.org/10.1016/S0305-7372(76)80019-9

[3] Fiallo, M.M., Kozlowski, H. and Garnier-Suillerot, A. (2001) Mitomycin Antitumor Compounds. Part 1. CD Studies on Their Molecular Structure. European Journal of 
Pharmaceutical Sciences, 12, 487-494. https://doi.org/10.1016/S0928-0987(00)00200-1

[4] Stevens, C.L., Taylor, K.G., Munk, M.E., Marshall, W.S., Noll, K., Shah, G.D., Shah, L.G. and Uzu, K. (1965) Chemistry and Structure of Mitomycin C. Journal of Medicinal Chemistry, 8, 1-10. https://doi.org/10.1021/jm00325a001

[5] Ogawa, K., Nomura, A., Fujiwara, T. and Tomita, K.-I. (1979) Crystal and Molecular Structure of Mitomycin C, an Anticancer Antibiotic. Bulletin of the Chemical Society of Japan, 52, 2334-2338. https://doi.org/10.1246/bcsj.52.2334

[6] Dowell, J.E. (2003) Mitomycin C Provides Little Additional Benefit in the Treatment of Carcinoma of Unknown Primary Site. Cancer Treatment Reviews, 29, 561-563. https://doi.org/10.1016/j.ctrv.2003.09.001

[7] Warner, D. and Brietzke, S.E. (2008) Mitomycin C and Airway Surgery: How Well Does It Work. Otolaryngology_Head and Neck Surgery, 138, 700-709. https://doi.org/10.1016/j.otohns.2008.02.011

[8] Bradner, W.T. (2001) Mitomycin C: A Clinical Update. Cancer Treatment Reviews, 27, 35-50. https://doi.org/10.1053/ctrv.2000.0202

[9] Doll, D.C., Weiss, R.B. and Issell, B.F. (1985) Mitomycin: Ten Years after Approval for Marketing. Journal of Clinical Oncology, 3, 276-286. https://doi.org/10.1200/JCO.1985.3.2.276

[10] Arora, S.K. (1979) Structural Investigations of Mode of Action of Drugs. I. Molecular Structure of Mitomycin C. Life Sciences, 24, 1519-1526. https://doi.org/10.1016/0024-3205(79)90036-5

[11] Yoda, N. and Hirayama, N. (1993) Structure-Activity Relationships for Mitomycins. Application of the Distance and Charge Analysis Method. Journal of Medicinal Chemistry, 36, 1461-1464. https://doi.org/10.1021/jm00062a019

[12] Hirayama, N., Arai, H. and Kasai, M. (1996) Structural Studies of Mitomycins. VIII. Mitomycin D Hydrate, $\mathrm{C}_{15} \mathrm{H}_{18} \mathrm{~N}_{4} \mathrm{O}_{5.1 .5} \mathrm{H}_{2} \mathrm{O}$. Acta Crystallographica C, 52, 2365-2367. https://doi.org/10.1107/S0108270196004350

[13] Kunz, K.R., Iyengar, B.S., Dorr, R.T., Alberts, D.S. and Remers, W.A. (1991) Structure-Activity Relationships for Mitomycin C and Mitomycin A Analogues. Journal of Medicinal Chemistry, 34, 2281-2286. https://doi.org/10.1021/jm00111a051

[14] Singh, S., Chang, A., Goff, R.D., Bingman, C.A., Gruschow, S., Sherman, D.H., Phillips, G.N. and Thorson, J.S. (2011) Structural Characterization of the Mitomycin 7-O-Methyltransferase. Proteins, 79, 2181-2188. https://doi.org/10.1002/prot.23040 